\title{
NEW SPECIES OF THE GENUS XYSTICUS (ARACHNIDA).
}

\author{
By Elizabeth B. Bryant.
}

Museum of Comparative Zoölogy, Cambridge, Mass.

In a recent revision of the spiders in the genus Xysticus at the Museum of Comparative Zoölogy, five new species have been found. Two more have been figured, one for the first time and the other to show more definitely the striking features of the palpus.

\section{Xysticus aprilinus sp. n. (Fig. 4).}

o. $5 \mathrm{~mm}$. long, cephalothorax $2.5 \mathrm{~mm}$. long, $2.5 \mathrm{~mm}$. wide.

Cephalothorax light, with a broad, brown stripe each side of the median light stripe, marginal markings faint and lacking the terminal light spots; dark spot at end of thoracic groove missing; abdomen much shrunken, showing no markings but occasional dark dots; abdominal bristles long; legs light with a light brown stripe edged with faint irregular dark marks on all legs, faint broken band at end of femur IV; sternum, venter and under sides of legs light; spines, I tibia, 4-2, no lateral, metatarsus 5-4, 1 lateral. Cephalothorax as long as femur I. Head very broad; bristles at edge of clypeus long. Epigynum longer than broad, very dark, with a simple round cavity showing no septum.

1 Texas; El Paso, 5 April, Soltau coll., N. Banks Collection.

The two broad, brown stripes on the cephalothorax, the light, unspotted legs makes this distinct from any other species. 
Xysticus coloradensis sp. n. (Figs. 1, 3, 7).

o $5.5 \mathrm{~mm}$. long.

Cephalothorax light, mottled brown each side of the median light stripe, ending with two pairs of small, dark spots on each side surrounded by a clear, cream color; the median light stripe with scolloped edges and faint dark marks behind the eyes, the usual dark spot at the end of the thoracic groove very small; bristles at the edge of the clypeus long; abdomen light with many small irregular dark marks with no distinct pattern; abdominal bristles long; legs light with many dark spots, light stripe on anterior legs indistinct; spines, I femur, many long spines on upper surface, tibia 4-4, the two middle pairs longer than the diameter of the joint, 3 lateral, metatarsus, 4-4, longer than diameter of the joint, 4 lateral, tarsus less than one half the length of the metatarsus. Cephalothorax as long as I femur. Sternum, coxae and venter light with small dark dots.

Palpus. The upper process of the tibia, ending in a sharp point under the tutaculum; the middle process prolonged into a large knob, the end covered with small bristles, between the upper and middle process is a large bristle; the lower process light colored, extending over the palpal organ, twisted with a broad tip. On the upper side of the tarsus are three long bristles. The tutaculum prolonged into a sharp process covered with curved hairs. The upper apophysis of the palpal organ is reduced to a small rounded knob; the lower is prolonged into a sharp curved point which rests on the outer curve of the tube.

o $6 \mathrm{~mm}$. long; cephalothorax $2.5 \mathrm{~mm}$. long, $2.5 \mathrm{~mm}$. wide.

The female has the same markings as the male; the scolloped edge of the light stripe is more pronounced. The abdomen is spotted and shows a faint serrate median light stripe. The legs are spotted and the light stripe faint, spines, I tibia, 4-3, the two outer middle ones as long as the diameter of the joint, no lateral; metatarsus, 3-3, 2 lateral. The tibia is very short, only once and a half the length of the patella. Cephalothorax longer than I femur. Sternum and venter light with scattered dark spots. 
Epigynum is a simple round cavity showing no median septum.

1 ô holotype. Col., Fort Collins, N. Banks Collection.

2 \& cotypes Texas; El Paso, 5 April, Soltau coll., N. Banks Collection.

2 \& New Mex.; Las Vegas, N. Banks Collection.

1 \& Col.; Ft. Reynolds, Dr. Miller coll.

It is probable that the two females from Texas are the same species as the male, as they have the same scolloped edge of the median light stripe, the two pairs of lateral spots on the cephalothorax, and the small dark spot at the end of the thoracic groove, and the spotted abdomen.

Xysticus floridanus Banks (Figs. 2, 5).

Trans. Amer. ent. soc.; 1896, 23, p. 70.

ô $3.2 \mathrm{~mm}$. long.

Cephalothorax clear, yellow-brown with a V-shaped light mark extending from the posterior lateral eyes to end of thoracic groove; abdomen with a serrate median light mark, bordered by three pairs of irregular brown spots, sides light brown; legs, femur I and II yellow-brown, tibia, darker brown, metatarsus and tarsus yellowish; posterior legs pale without markings; sternum and venter pale. Cephalothorax shorter than femur I. Head very broad. Spines, I femur 3, tibia 4-4, long spines, no lateral, metatarsus, 3-3, the second and third very long, and no lateral.

Palpus. Tibia with the usual three processes ; the upper, a pointed flattened lobe; the middle a broad plate-like projection, and the lower a slender curving hood. The palpal organ is very simple. The upper apophysis is missing and the lower is light colored and in the lateral view appears only as a slight swelling in the lower part of the palpus. The tutaculum is very small.

1 o holotype. Fla.; Punta Forda. N. Banks Collection.

Xysticus fraternus Banks (Figs. 6, 8).

Journ. N. Y. ent. soc.; 1895, 3, p. 90.

Xysticus hamatus Keyserling, Verh. z. b. Ges. Wien, 1884,34 , p. 521, pl. 13, fig. 22 (name preoccupied by Thorell, 1875). 
Xysticus hamatinus Banks, Bull. U. S. nat. mus., 1910, p. 48.

In his description, Keyserling fails to describe the palpus and the only figure given omits the most striking character. This, Mr. Banks described as "a long plate-like piece projecting straight across the bulb towards the top of the palpus." The lower of the two apophysis usually found in the center of the palpus is prolonged into a slender piece which extends obliquely across the center; the upper apophysis is reduced to a small darkened, obtuse point which lies under the upper end of this piece. The end of the tube is bent almost at right angles and is probably one of the dark hooks figured by Keyserling.

The tibia has the usual three processes, the upper, resting against the tarsus, under the tutaculum, the lower a broad flattened piece and the middle reduced to a very small projection between the two. The palpus is much larger than is usual in the genus.

The type of Keyserling is from Bee Spring, Ky. Mr. Bank's type is from Sea Cliff, N. Y. In the M.C.Z. collection it is found from Cohasset, Mass. (17 June, 1914, E. B. Bryant Coll.) south to Falls Church, Va., and west to Las Vegas, New Mexico.

Xysticus keyserlingi sp. n. (Figs. 9, 10).

î $4.2 \mathrm{~mm}$. long.

The cephalothorax with sides mottled with brown, much darker at the posterior part, median pale stripe with brown markings to form lyre-shape mark, ending with inconspicuous dark spot at the end of the thoracic groove; abdomen with median spear-shape mark of brown, and three pairs of lateral brown marks; anterior sides almost white; legs mottled with brown, I and II with distinct brown stripe; spines I tibia, 4-4, metatarsus, 4-4, longer than diameter of joint, 2 lateral. Sternum, underside of legs and venter mottled with brown. Cephalothorax longer than I femur.

Palpus. Tibia with the usual three processes, the upper a flattened lobe ending in a distinct spine bent at right angle; the middle process lobed and the lower long, slender 

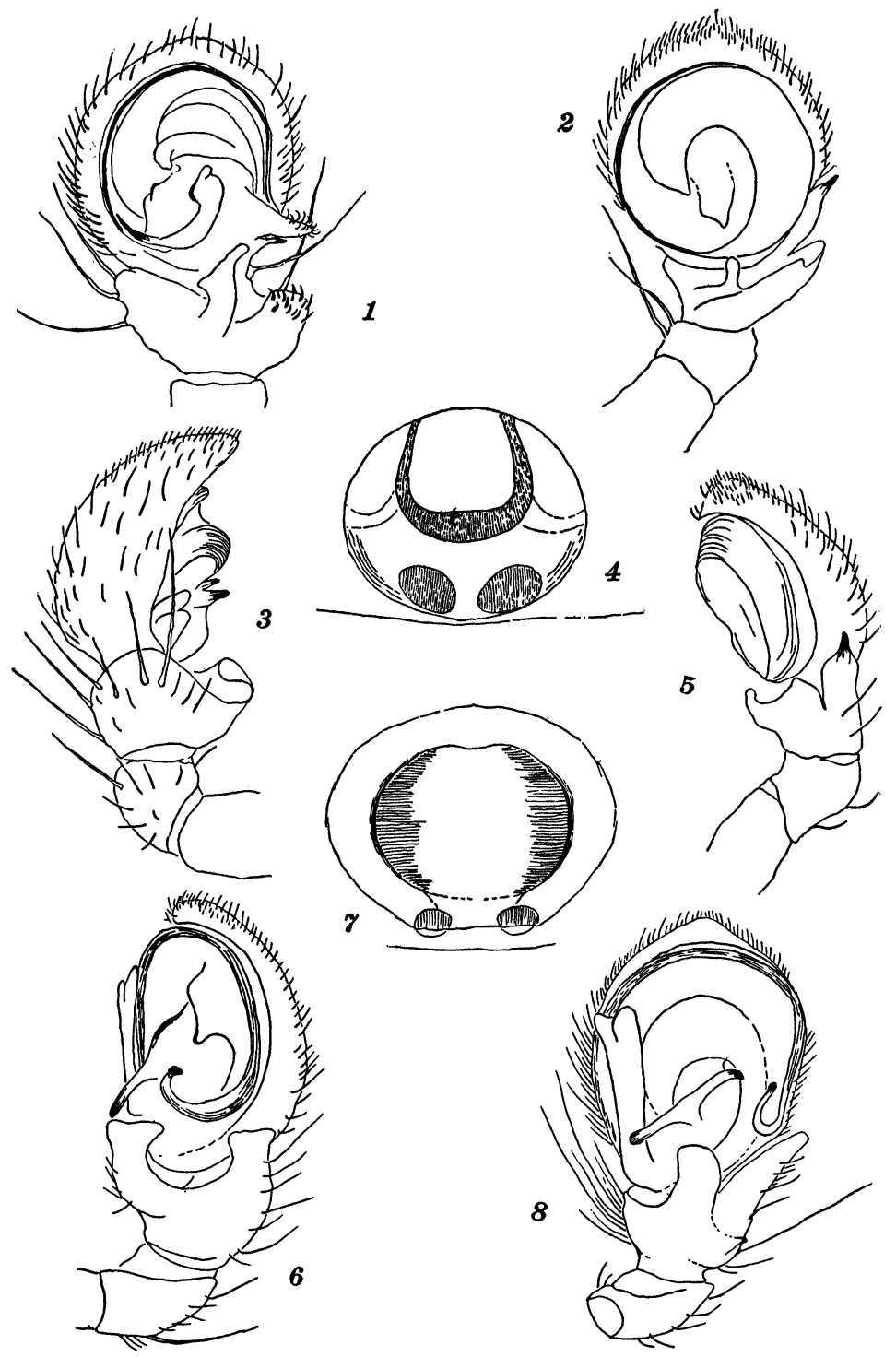

Plate 7

Bryant-Xysticus 

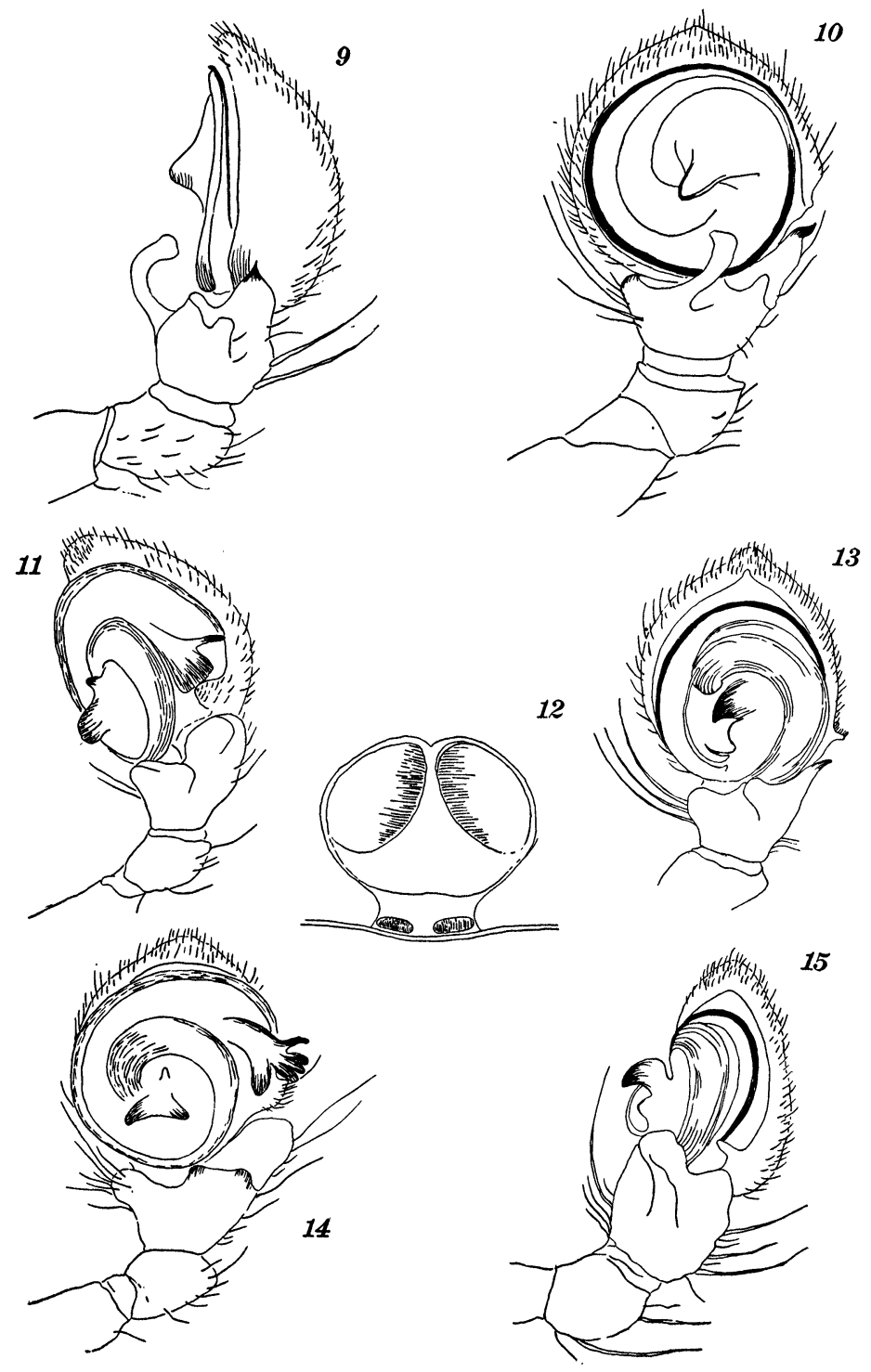

Plate 8

Bryant-Xysticus 
and curving, two-thirds the length of the palpus. On the upper side of the tibia are two long bristles. The palpal organ is simple. The tube extends once and a half around the palpus. The lower apophysis is missing and the upper is white, spatulate with a thickened edge. The tutucalum is very small.

1 î holotype. New Mexico; Las Vegas. N. Banks Collection.

Xysticus pallidus sp. n. (Figs. 11, 12, 14).

ô $3.5 \mathrm{~mm}$. long.

The cephalothorax pale mottled brown on each side ending in a darker brown spot, small dark spot at end of thoracic groove; abdominal marks characteristic of the genus, a central serrate light stripe, with four pairs of dark lateral marks. Anterior legs light with very small dark spots, with pale line on femur and tibia; posterior legs with larger, dark spots, and dark rings at end of femur IV and basal end of tibia. Few spines on femur I, tibia 4-4, longer than diameter of joint, 2 lateral, metatarsus, 4-4, longer than diameter of joint, 2 lateral, tarsus more than half the length of metatarsus. The cephalothorax as long as femur I.

The palpus is large. The tibia has the usual three processes, the upper large and broad, the middle broad and short and the lower a rounded knob with many long hairs. The tube of the palpal organ is bent at the tip at right angles as in $X$. stomachosus, and is supported by a lobed process. The upper apophysis is reduced to a small point and the lower is bilobed.

\& $4.5 \mathrm{~mm}$. long.

Cephalothorax pale brown on each side, with two pairs of darker brown spots; posterior part white, small dark spot at end of thoracic groove; abdomen lighter than cephalothorax without distinct marks. Anterior legs light and covered with many fine spots, the light stripe distinct on upper side of femur, patella and tibia; posterior legs pale with a distinct dark spot on the femur and a broken band at the distal end, patella with a dark spot at the tip, tibia with dark spot, near and one at the tip; spines of 
legs, I tibia 4-3, no lateral, metatarsus, 4-4, 2 lateral; sternum light with many small dark dots. Cephalothorax longer than I femur.

The epigynum is large and dark.

1 i holotype, 1 \% allotype; Mass.; Ipswich on beach, 14 June, 1914. E. B. Bryant Collection.

This pair was found with the cocoon at the head of the beach under trash. It was first identified as a small $X$. stomachosus but closer examination shows that it is a different species. In $X$. stomachosus the spins on tibia I are 7-5, metatarsus 5-5. And the palpus and epigynum are quite different.

Xysticus vernalis sp. n. (Figs. 13, 15).

\section{o $3.5 \mathrm{~mm}$.}

Cephalothorax dark mottled brown, with a broad median light stripe shaded with light brown at the anterior end, and a distinct dark spot at the end of the thoracic groove; abdomen with the characteristic markings of the genus, a pair of oblique lateral marks at the basal end and three pairs of transverse marks, connected by a median spot; sternum and venter light with many dark spots; legs brown, showing a light line bordered with dark on femur; patella and tibia; tibia and metatarsus lighter than femur; anterior tarsi light; spines, I few scattered on upper side of femur, tibia 4-4, two middle pair longer than diameter of joint, 3 lateral, metatarsus, 3-3, the two middle pair longer than diameter of the joint, 2 lateral. Cephalothorax as long as femur I.

Palpus. The upper process of tibia ends in a short, obtuse recurved spine, the middle process a blunt spatulate lobe and the lower process an inconspicuous knob bearing three long bristles. Three long bristles on the inner side of the tibia. In the palpal organ the upper apophysis is large, dark and bent downward, the lower is slender, dark and pointed, the two are separated by a clear white spatulate lobe. Below the lower process is a long slender filament lighter in color than the two median, which extends up and reaches the beginning of the bulb. The tutaculum is small and is edged with short curved hairs. 
1 ô holotype, Mass.; Petersham 27-31 May, 1913. E. B. Bryant Collection.

Cotypes:

1 ô N. S.; Cape Breton, N. Sydney, July, 1906. E. B. Bryant Collection.

1 ô Me.; Portland Harbor, Long Is., June, 1901. E. B. Bryant Collection.

3 o $\quad$ N. H.; Mt. Washington. N. Banks Collection.

1 ô Mass.; Holliston, 22 June, 1924. J. H. Emerton coll.

1 o N. Y.; Sea Cliff. N. Banks Collection.

1 ô Ala.; Auburn. N. Banks Collection.

1 ô Ill.; Chicago. N. Banks Collection.

1 ô Iowa; Ames. N. Banks Collection.

Explanation of Plates

Plate 7.

Fig. 1. $X$. coloradensis sp. n., ventral view of palpus.

Fig. 2. $X$. floridanus Banks, ventral view of palpus.

Fig. 3. $X$. coloradensis sp. n., lateral view of palpus.

Fig. 4. $X$. aprilinus sp. n., epigynum.

Fig. 5. $X$. floridanus Banks, lateral view of palpus.

Fig. 6. $X$. fraternus Banks, lateral view of palpus.

Fig. 7. $X$. coloradensis sp. n., epigynum.

Fig. 8. $X$. fraternus Banks, ventral view of palpus.

Plate 8.

Fig. 9. $X$. keyserlingi sp. n.. lateral view of palpus.

Fig. 10. $X$. keyserlingi sp. n., ventral view of palpus.

Fig. 11. $X$. pallidus sp. n., lateral view of palpus.

Fig. 12. $X$. pallidus sp. n., epigynum.

Fig. 13. $X$. vernalis sp. n., ventral view of palpus.

Fig. 14. $X$. pallidus sp. n., ventral view of palpus.

Fig. 15. $X$. vernalis sp. n., lateral view of palpus. 

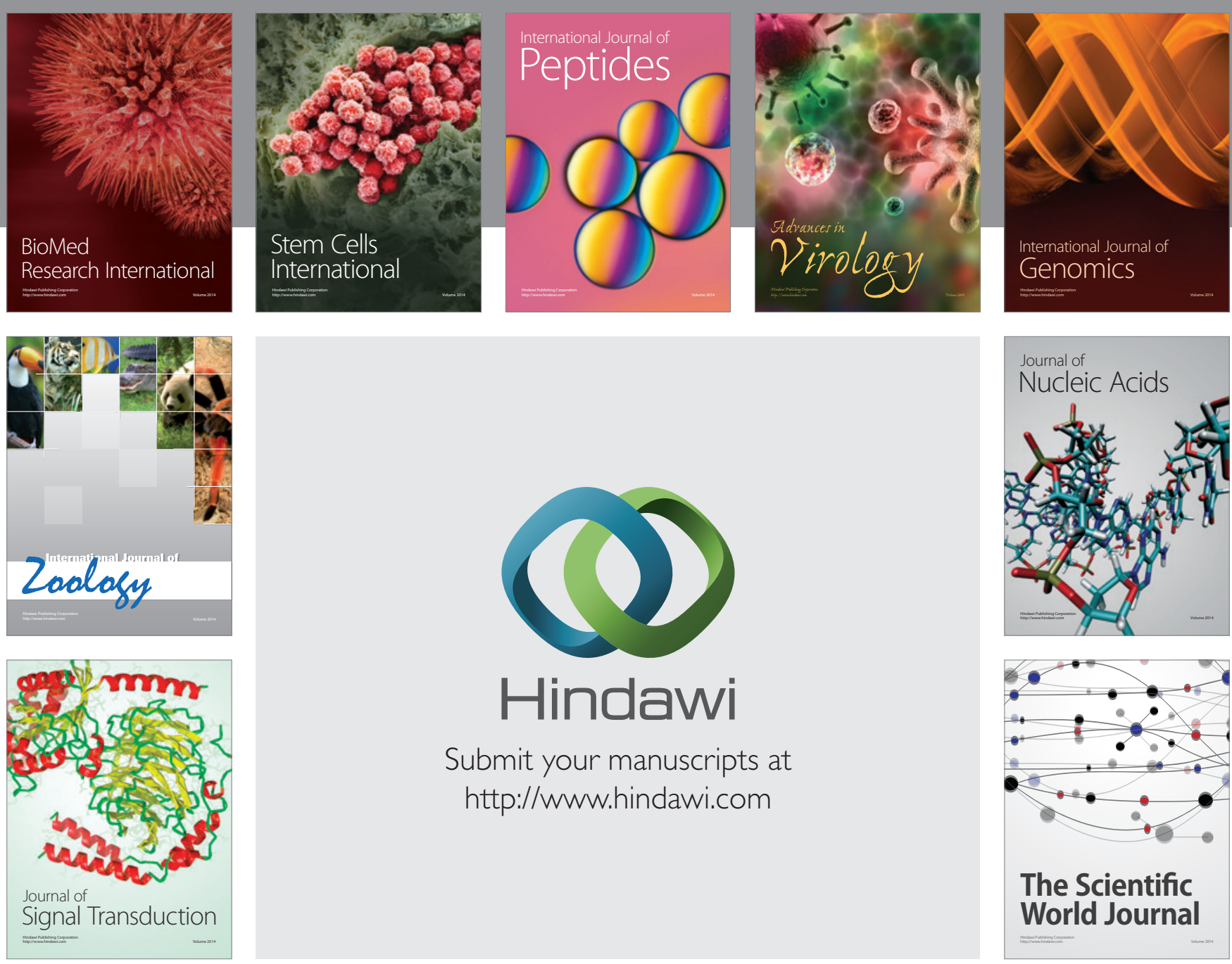

Submit your manuscripts at

http://www.hindawi.com
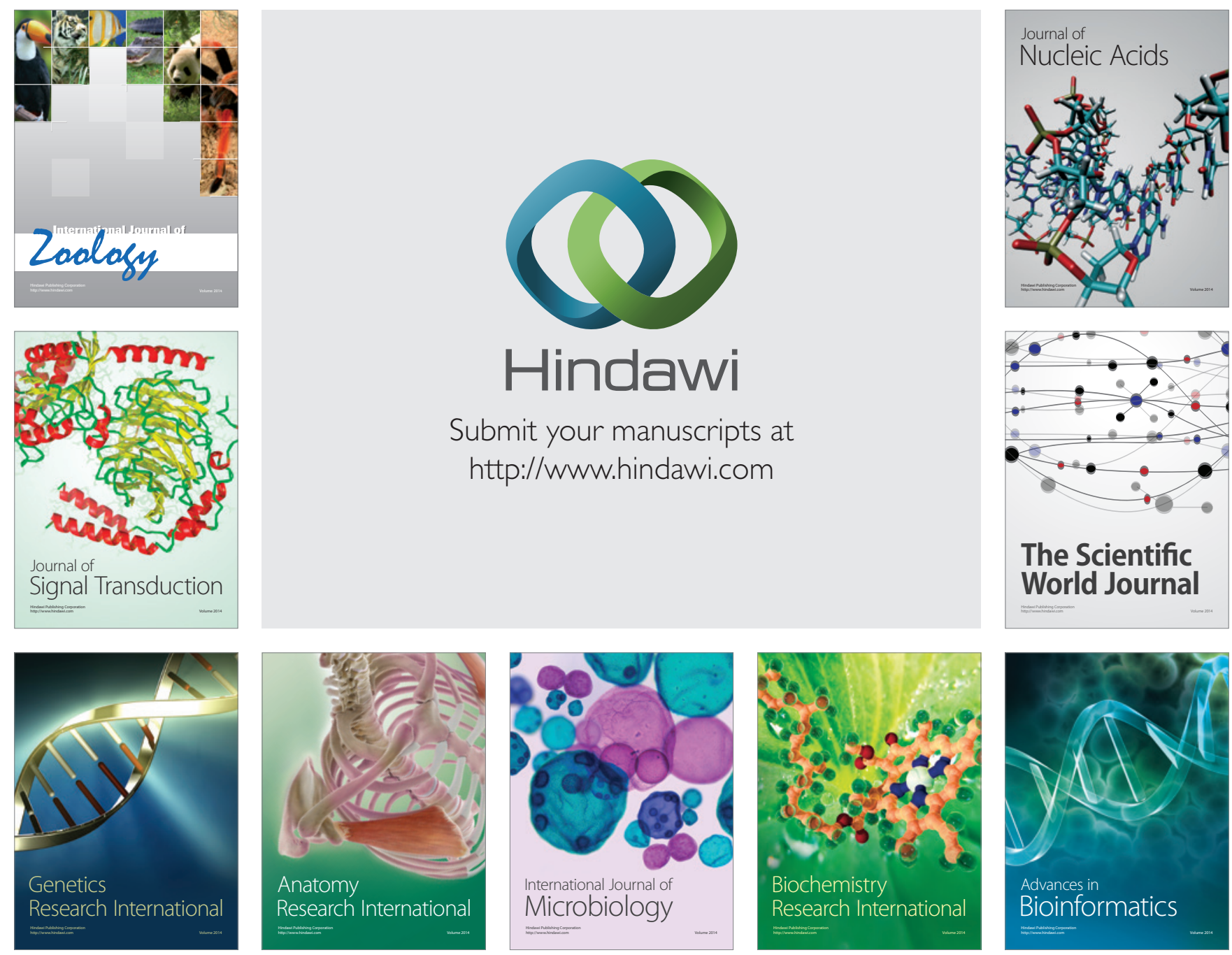

The Scientific World Journal
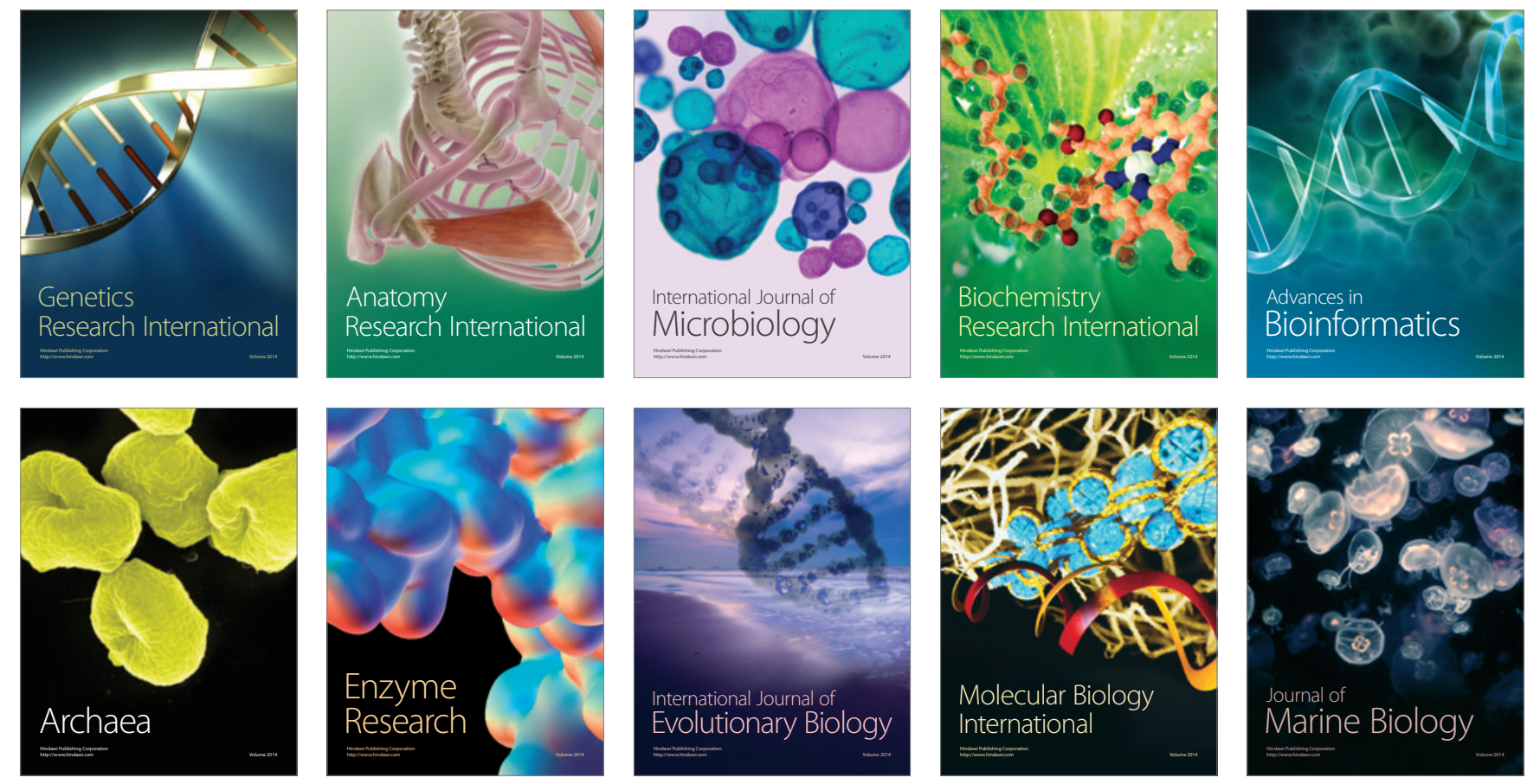